\title{
Hydromycoflora of thirty-one lakes in Ełk Lake District and adjacent waters with reference to the chemistry of the environment*
}

\author{
BAZYLI CZECZUGA \\ Department of General Blology, Medical Academy. \\ Kiliniskiego 1, 15-230 Bialystok, Poland
}

\begin{abstract}
$\mathrm{C} z \operatorname{cc} t \mathrm{ug}$ a B: Hydtomycoflont of thirty-one lakes in Efk Lake District and adjacent waters with refereace to the chemistry of the onvironment. Aela Mycol. 30 (1): 49-63, 1995.

The raycoflor of Lake Etk and thirty-one adjacent lakes and six rivers was studied. Samples of water were collected in 1987-199| for hydrochemical analysis and determination of fungi species. In total 123 species of fungi were found in these water bodies, including 9 species reported for the first tine from Poland.
\end{abstract}

Key words: Hydromycoflora, aquatic fungi, lakes, rivers.

\section{INTRODUCTION}

Among aquatic fungi there are some very common species which arc found in almost every water basin any time of the year. However, there are also very rare species which are sporadically encountered in few water reservoirs. The distribution and biology of some fungi have not been thoroughly studied to date (S p a r r o w, 1960; K a r l in g, 1977). Therefore, it secms necessary to determine the types of water bodies in which there species occur and their chemistry.

The determination of these phenomena is possible only by means of hydromycological studics of numcrous ecological sites on extensive area.

This study is part of large-scale investigations conducted in the north-eastern region of Poland. Previous studies have provided some inhibition about new sites of very rare aquatic fungi, which have not been encurritered in Poland so far (C z cczuga, Próba, 1980; C z c c zuga et al., 1989).

The data on the hydromycoflora of Elk lakes and adjacent waters enrich our knowledge of biology of many aquatic fungi species and provide information about new species, which have not been found in water bodies in Poland to date. 


\section{THE STUDY AREA}

The studies were carried out in 31 lakes and 6 rivers belonging to the so-called group of Ełk Lakes located in the south-eastern part of the Mazurian Lake District. These lakes were formed as a result of the melting of huge lentides, the soterrmed dead ice ( $\mathrm{C}$ z e c z u g a, 1987). The morphological data of these water bodies are provided in Table 1. These lakes are of tunncl-valley character with the exception of Lake Kroszewo, Polne, Toczyłowo and Tajno which are of pond type. Most of them are surrounded by forest, ploughlands and marshy meadows.

The investigated rivers connect of some of these lakes whereas the longest River Ełk falls into the lower course of the river Biebrza as its right-bank tributary.

I thank or E. Muszy f ska. de L. Woronowiczand M. J on I k for help in the investigations.

\section{METHODS}

Samples of water were collected once a month over the years 1987-1991 for hydrochemical analysis and studies of species composition of aquatic fungi. For the determinations of chemical properties of water, the methods recommended by Standard Methods (G o I t e r m a n, C ly m o. 1969) were cmployed; the details of these methods were described in a previous paper ( $\mathrm{C} z$ e c z u g a, P r ó b a, 1980).

In the water zoosporic fungi were studicd by direct microscopic examination of water samples collected from materials in the water as well as by bait method Fulle r and J a wors k i (1986) (onion, skin, hemp-seeds, clover-seeds, hairs and fillings of horn). In addition (for Hyphomycetes) the foam collected from the surface of eddies in running water or at the edges of stagnant water was examined directly under a microscope. The samples were fixed in formalin-acetic-alcohol immediately after collection and transported to the laboratory.

For the identification of the fungi the following keys were used: (Sk irg i e f f o, 1954; S p a r row, 1960; B a t k o, 1975; I ngo I d, 1975; K a r I in g, 1977 and Dudka, 1974, 1985).

\section{RESULTS}

The results of the chemical analysis of water are presented in Table 2 . The lowest mean oxidability was noted in Lake Białe Rajgrodzkie and the highest in Lake Nieciecz. The ammonium nitrogen content was the lowest in Lake Białe Rajgrodzkic and River Ełk (site c) and highest in Lake Haleckie. The lowest concentration of undetectable amounts) nitrite nitrogen was nobed in Lakes Lipiriskie. Mierucie, Rekelt, Skomętno, Straduny, Sunowo, Szostak and Rivers Etk (site a), Rózanka and Swiẹcek, whereas the highest in Lake Drę́́stwo. Nitrate nitrogen on the other hand, was not found at all in Lake Straduny. The highcst concentration of this form of nitrogen was noted in Lake Skomętno. 
Table 1

Morphological characteristic of the investigated water bodies

\begin{tabular}{|c|c|c|c|c|}
\hline \multirow{2}{*}{ Lake } & \multirow{2}{*}{$\begin{array}{l}\text { Area } \\
\text { in has }\end{array}$} & Maximum & Mean & \multirow{2}{*}{$\begin{array}{l}\text { Number } \\
\text { of sites }\end{array}$} \\
\hline & & \multicolumn{2}{|c|}{ depth, in m } & \\
\hline 1. Biale Rajgrodakic & 135.4 & 35.1 & 10.5 & 2 \\
\hline 2. Berowe & 2240 & 32.0 & 5.7 & 3 \\
\hline 3. Dhugochwaty & 43.9 & 6.7 & 2.6 & 2 \\
\hline 4. Drę̧istwo & 550.2 & 25.3 & 7.0 & 3 \\
\hline 5. Druglin & 5033 & 6.4 & 2.4 & 4 \\
\hline 6. Dybowskic & 149.8 & 17.0 & 4.7 & 2 \\
\hline 7. Elk & 385.0 & 55.8 & 150 & 8 \\
\hline 8. Gawlik & 3920 & 10.5 & - & 2 \\
\hline 9. Golubskie & 47.0 & 4.2 & 19 & 1 \\
\hline 19. Grabnik & 22.2 & 5.6 & 2.6 & 1 \\
\hline 11. Haleckie & 90.0 & 7.2 & 3.3 & 1 \\
\hline 12. Henzelewo & 128.9 & 13.3 & 3.3 & 2 \\
\hline 13. Kroszewo & 32.5 & I.5 & - & 1 \\
\hline 14. Krzywe Rajgrodzhie & 88.4 & 8.2 & - & 1 \\
\hline 15. Lasmiady & 942.9 & 43,7 & 9.5 & 3 \\
\hline 16. Lipinskie & 272.1 & 23.0 & 3.5 & 3 \\
\hline 17. Micrucie & 23.0 & 2,4 & - & 1 \\
\hline 18. Nieciecz & 400 & 7.7 & - & $i$ \\
\hline 19. Polne (near lake Mierucie) & 10 & 0.5 & - & 1 \\
\hline 20. Raggrodzkie & 15000 & 51.8 & 14.3 & 7 \\
\hline 21. Regielskic & 87.5 & 11.0 & 3.8 & 2 \\
\hline 22 Reklet & 587 & S.5 & 2.3 & 1 \\
\hline 23. Skomętroo & 209.6 & 7.0 & 2.0 & 3 \\
\hline 24. Straduny & 53.0 & 4.9 & 2.4 & 2 \\
\hline 25. Suncwo & 168.1 & 20.6 & 9.3 & 3 \\
\hline 26. Szóstak & 490.1 & 28.4 & 9.1 & 4 \\
\hline 27. Selmęı Wielki & 12020 & 21.9 & 7.8 & 11 \\
\hline 28. Tajno & 216.4 & 6.6 & 5,0 & 3 \\
\hline 29 Toczytowo & 950 & 9.9 & 8.2 & 2 \\
\hline 30. Woszczelskic & 147.0 & 10.6 & 3.4 & 2 \\
\hline 31. Wydmińskie & 3370 & 9.8 & 3.1 & 3 \\
\hline River & $\begin{array}{l}\text { Lenght, } \\
\text { in } \mathrm{km}\end{array}$ & \multicolumn{3}{|c|}{ Number of sites } \\
\hline $\begin{array}{l}\text { 32. Etk-flow to River Bicbraa } \\
\text { a-site in Stradusy } \\
\text { b-site beforc Lake EL } \\
\text { e- after Lake Elk } \\
\text { d-site in Nowa WieS Elckat } \\
\text { e-site near Grajewe }\end{array}$ & 113,6 & \multicolumn{2}{|l|}{5} & \\
\hline 33. Golubica - flow to Lake Selmę Wielki & 5.0 & \multicolumn{3}{|c|}{1 (near Lake Sclmęı Wielki) } \\
\hline 34. Lega-flow to Lake Selmęt Wiclki & 110.5 & \multicolumn{3}{|c|}{4 (Paf́ki, Sedranki, Moone, Nowy Mlyn) } \\
\hline $\begin{array}{l}\text { 35. Malkinia - flow to Lake Kajgrodzkie } \\
a-\text { sitc in Stucze } \\
\text { b-site in Sypitki }\end{array}$ & 11.5 & \multicolumn{3}{|c|}{2} \\
\hline 36. Rózanka - flow to River Święcek & 7.2 & \multirow{2}{*}{\multicolumn{3}{|c|}{$\begin{array}{l}1 \text { (near River Swięcek) } \\
2 \text { (near Lakes: DHugochwaly and Ros) }\end{array}$}} \\
\hline 37. Swięcek - flow Lake Ros & 19.5 & & & \\
\hline
\end{tabular}




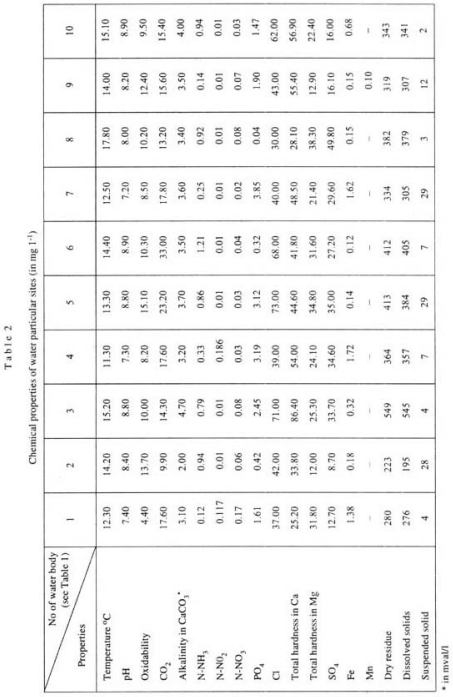




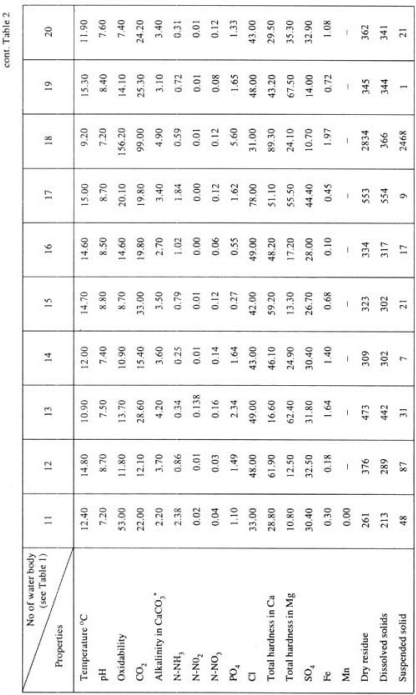




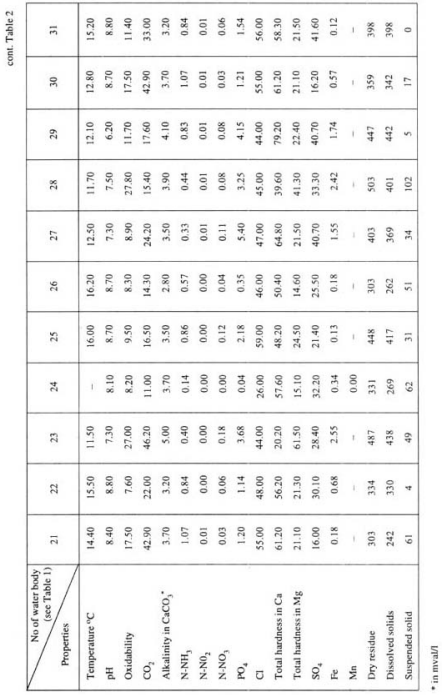




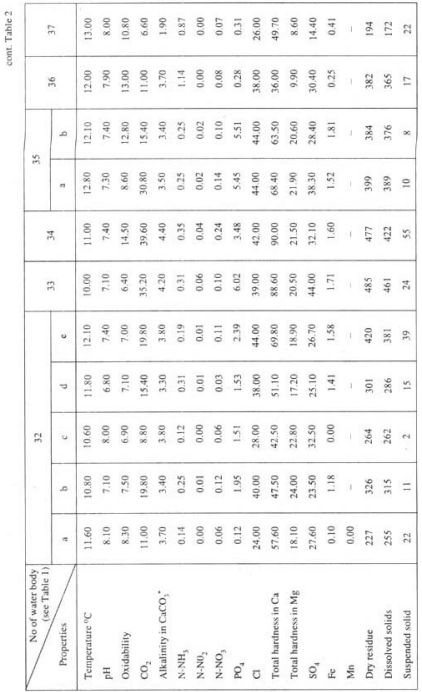


The lowest concentration of phosphorus was found in Lake Gawlik; the highest - in the waters of Rivers Golubica and Małkinia and Lakes Nieciecz and Selmęt Wielki. The remaining chemical properties of water variet greatly.

The water of Lake Woszczelskie in June 12, 1992 was red. It had the highest content of cells of three species of purpuric bacteria - Lamprocystis roseopersicina (Kutzing) Schroeter, Thiopedia rasea Winogradsky and Thiocystis violacea Winogradsky.

In total 123 species of aquatic fungi were found in the water bodies (Table 3): 36 species belonging to Chytrydiomycetes, 2 to Hyphochytriomycetes, 55 to Oomycetes, 2 to Zygomycetes, 2 to Ascomycetes, 3 to Endomycetes and 23 species to Hyphomycetes. It was noteworthy that some aquatic fungi species were new to the Polish hydromycoflora such as: Cladolegnia asterophora, Olpidium pendulum, Achlya oblongata, Curvularia lunata (Fig. 1) and from Hyphomycetes - Cylindrocarpon aquaticum, Descalsia cruciala and Tricladium patulum. Rare species in the mycoflora of Poland included Lageniudium rabenhorstii, Skirgiella septigena, Dangeardia laevis, Septolipidium lineare, Zoophthora conica and Z. curvispora.

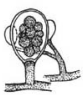

A

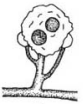

B

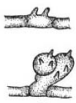

C

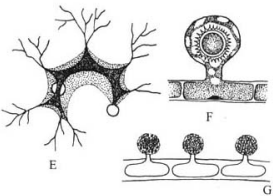

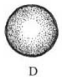

D
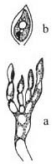

$\mathrm{H}$

Fig. 1. Soane aquatic fongi

A - Achlya oblongata-zametangium (54-176 $\times 44-120 \mu \mathrm{m})$; B - Cladolegnia asterophora-gannetangium $(32-46 \mu \mathrm{m}): \mathrm{C}$ - Cervelaria innata - part of thalles; D - Otpidium pendelum - sporangium (24-28 $\mu \mathrm{m})$; $\mathrm{E}$ - Phlyctorhiza endogena - thallus in insect axuviac; F - Skirgiella septigeas - spore (16-22 $\mu \mathrm{m})$ in thal lus; G - Septolpidium lineare - thallus $(8 \times 24 \mu \mathrm{m})$ in algac celol: H $-Z$ (oophthora coaica - a - part of thallus from conidioghore, $b$ - conidium. 


$$
\text { Table } 3
$$

Aquatic fungi in particular water bodies (except for Lake Elk)

\begin{tabular}{|c|c|}
\hline Class and species & Water bodies (see Tuble 1) \\
\hline Chytridiomycetes & \\
\hline Asterophlyctis irregularis Karling. & 7 \\
\hline Blastocladia ramosa Thacter & 6 \\
\hline B. rostrata Minden & $32 \mathrm{~d}$ \\
\hline Blastocladiopsis parva (Whirfen) Sparrow & $1,2,5,7,12,15,20,23,25,26,27,29,32 c, 35 a$ \\
\hline Caten aria anguillulae Sorokin & $5,7,13,14,21,27,32 \mathrm{~b}, \mathrm{~d} ; 34$ \\
\hline C. sphaterocanpa Karliag & $14,27,29$ \\
\hline C. verrucosa Karling & $7,17,19,22,36$ \\
\hline Cutenophlyctis variabilis (Karling) Karling. & 7,30 \\
\hline Chytridium xylopailum Comu & $3,7,10,12,17,20,21,22,23,24,25,27,32 b, d, c_{;} 35 a$ \\
\hline Chytrionyces poculatus Willoughby et Townley & 13,17 \\
\hline Chytnomycetes annuiatus Dogma & $7,9,21,29,31 \mathrm{c}, 32 \mathrm{~b}$ \\
\hline Dangeardia leevis Sparrow et Bart & 7 \\
\hline Dictyoarorpha dioica (Couch) Mullins & 27 \\
\hline Diplophlyctis complicata (Willoughby) Batko & 4 \\
\hline Karlingia chilinophila Karling & 30 \\
\hline K. poicnica Hassan & $32 \mathrm{~d}$ \\
\hline K. nosea (de Bary et Woronin) Johanson & $27,30,31,34,35 \mathrm{~d}$ \\
\hline Nowukowskiella elegans (Nowak ) Schrueter & $3,7,9,10,16,18,27,31,32 \mathrm{a}, \mathrm{d}, \mathrm{c}, 33,35 \mathrm{a}, 36 \mathrm{~b}$ \\
\hline Nowakowskiella macrospora Karling & $1,2,3,4,7,27,28,32 d$ \\
\hline Oipidiem granulatum Karling & $7,14,20,27,32 \mathrm{a}, \mathrm{d}$ \\
\hline O. pendulum Zop! & 31 \\
\hline Phlyctidiam apopinyxalum Canter & 20 \\
\hline Phlyctochytrium aurelias Ajello & $7,16,26$ \\
\hline Phlyetorhiza endogena Hanson & 33 \\
\hline Polychytrium aggregatura Ajello & $7,16,24,27,32 \mathrm{~d}, 35 \mathrm{a}$ \\
\hline Polyphagus euglenae Nowakowski & $5,7,11,32 d, c$ \\
\hline Rhizidionyces bivellatus Nabel & 20 \\
\hline Khzoptydiem apiculatura Karling & $3,4,7,20$ \\
\hline R. carpophilum (Zopf) Fisher & $7,14,27,32 \mathrm{~d}$ \\
\hline R. keratinophifam Karling & $1,3,4,5,7,13,20,23,32 \mathrm{~b}$, e; $35 \mathrm{a}$ \\
\hline R. aodialosum Karling & 27,29 \\
\hline$R$. poligenum Ookubo et Kobayashi & $27,32 \mathrm{e}$ \\
\hline Rhizephydiura pollinis-pini (Braun) Zopf & $3,7,17,18,23,25,27,30$ \\
\hline Septolpidiurn lincare Sparrow & 18 \\
\hline Siphonaria variabilis Petersen & $4,7,20,32 \mathrm{~d}$ \\
\hline Skingiella septigena (Comu) Batko & 7 \\
\hline Hyphochytriomycetes & \\
\hline Hypochytrium catenoides Karling & $5,7,10,14,22,25,27,30,31$ \\
\hline Rhizidiomyces bivellatus Nabel & 20 \\
\hline Oomycetes & \\
\hline Achlya americana Hemphrey & $32 \mathrm{a}$ \\
\hline A. debaryana Humphrey & $7,12,20,27,32 d$ \\
\hline A. dubia Coker & $32 \mathrm{~d}$ \\
\hline A. flagellata Coker & $7,29,32 a$ \\
\hline A. glomerata Coker & 7 \\
\hline A. hypogyna Shanor et Conover & 27 \\
\hline A. Klebsiana Pieters & 7 \\
\hline A megasperma Humphrey & $3,7,12,20,26,32 \mathrm{c}$ \\
\hline A obloagata de Barry & 7,31 \\
\hline
\end{tabular}


A. oligacantha de Bxrry

A. papillosa Humphrey

A. polyandra Hildebrand

A. radiosa Maurizio

A. recurva Cornu

A. rodrigueziana F. T. Wolf

Aphanodictioa papillatum Huneycutt

Aphanomyces astaci Schikera

A. irregularis Scolt

A. keratinophilus (Ookubo et Kobayashi)

Sey, et Jch.

A. laevis de Barry

A. parasiticus Colket

A. scaber de Barry

A. stellatus de Bary

A poodachlya brachynema (Hildebrand) Pringsheim

Cladolegnia askerophora (de Barry) Johanes

C. uaispora (Coker et Couch) Johanes

Culvufaria Junata ( $W_{\text {alker }}$ ) Beedijn

Dictyuchus monosporus Leitgeb

Isoachlya asisospora (de Bary) Coker

Lagenidium marchalianum de Wildeman

L. rabenhorstil Zopf

Leptolegaia caudata de Barry

Leptolegniclla keratinophila Huncycu tt

I. cpromirus Iacucus (Roth) Agardh

Mitochytridium regale Hassan

Myzocytium microsporum (Karling) Sparrow

M. proliferum Sehenk

Olpidiopsis saprolegniae (Braun) Comu

Phythiogeion rigricans Batko

Phytium uniforme Lund

$P$. artotrogus de Barry

P. debaryanum Hesse

P. rostratum Butler

$P$. ultimum Trow

Rhizidium chitinophilum Sparrow

Rozellopsis inflara (Butier) Karling

Saprolegnia delica Coker

S. dictinat Humphrey

S. ferax (Gruith) Tumet

S. hypogyna (Pringsheim) de Barry

S. mixtai de Barry

S. monoica Pringshcim

S. parasitica Coker

Traustotheca clavata (de Barry) Humptey

Zoophagus insidians Sommerstorff

Zygomycetes

Zoophthora conicu (Nowakowski) Batko

2. curvispora (Nowakowskj) Batko

\section{Ascomycetes}

A postemidiam gueraisaci (Crosan ) Boud

Aspergillas candidus Link cont. Table 3

$2,7,9,10,26,27,33,34$
$1,3,7,27,32 \mathrm{~b}$
$27,32 \mathrm{~d}$
$35 \mathrm{a}$
7,15
27,30
$7,9,21,23,33$
$7,32 \mathrm{~d}$

$1,2,3,5,6,7,9,12,14,16,17,19,20,21,22,25,26$

$27,28,30,31,32 d, c ; 34$

27

4,27

1. 7.27

7

$3,7,15,20,25,27$

7

$32 a$

7

$7,14,20,29,33$

$1,3,5,7,10,11,13,21,27,29,30,32 \mathrm{~b}, \mathrm{c}, 33,35 \mathrm{~b}$

$20,25,27,28,29,30,32 \mathrm{~d}, \mathrm{c} ; 35 \mathrm{~b}$

7

27

$2,7,12,21$

32d, c, 33

6. $7,20,27$

$3,7,19,21,27,28$

$32 \mathrm{c}$

33

$3,7,20,25,26,27,29,32 e, 33$

$5,7,26,27,28,29,30,32 \mathrm{~d}, \mathrm{c} ; 35 \mathrm{a}, \mathrm{b}, 37$

$32 \mathrm{a}$

$13,18,25,27,32 \mathrm{~b}, \mathrm{c}$

7

$16,24,27$

$7,17,20,27$

20

$3,6,9,20,22,23,25,27,28,32 a, d ; 33,35 a, 36$

36

24,27

$1,2,3,7,11,12,14,15,17,18,20,25,27,28,29,324$, e $33,34,35$ a, 37

$13,35 b$

$32 \mathrm{a}$

7

$7,12,14,19,21,22,26,27,32 \mathrm{a}, 33$

7

$1,7,12,16,19,20,21,22,25,27,28,32 a, b, d$

$7,15,27$

15

7.27

26 


\section{Endomycetes}

Candida albicans (Rubin) Berkhout

C. tropicalis (Cast) Berkhout

Trichosporan cetancum (de Beur. et all.) Ota

\section{Hyphomyceres}

Alutospora acuminata Ingold

Anguillospora gigantea Ranzoni

A. Inngissima (Sace et Sydow) Ingold

A. psetidolongissima Raneoni

Anthrobotrys oligespora Frescaius

Bacjlliospona aquatica Nillsson

Cylindrocarpon aquaticum (N)lisson)

Marvanova et Dessals

Dactylleat submersa (Ingold) Nitswon

Descalsia cruciata Roldan of Honnubia

Fusarium aquacductum (Radlk. et Rabenh.) Lagerh

Geniculospora inflata (Ingold) Nilsson

Heliscus lugdenensis Succar, et Therry

Lemonniera aqualica de Wildeman

L. terrestris Tubaki

Lumabspora curvala Ingold

Robillsvia phrugmitis Cunnel

Tetrachaetum elegans Ingold

Tetracladiunt marchalianuta de Wildeman

T. setigerum (Grove) Ingold

Tricladium patulum Maryanova et al.

Tripospermurn camelopurdus Ingold ot al.

Triscelosphons raonospores Ingold

Varganyces aguaticum (Dudka) Toth

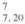

$7,12,13,22,27,29,32 d$

14. 25,31

7

1. $2,3,7,9,13,16,20,22,24,26,27,30,32 \mathrm{~b}, \mathrm{~d} ; 34,36,37$ 18

$7,15,17,25,27,28,30,31,32 \mathrm{~b}, \mathrm{e}, 33$

$2,4,6,7,37$

22

$7,27,31$

12

$6,7,18,20,22,32 \mathrm{~d}$

7

7.27

1. $7,14,15,20,27,29,30,32 \mathrm{~s}$, d; 34

7,34

$7,27,34$

$7,25,27,31,32 \mathrm{a}, \mathrm{d} ; 34,37$

7.27

25,27

1. 6. 7. 15, 19

7

12

7,27

3. $32 \mathrm{e}$

Cladolegnia asterophora was observed in the water collected from the River Elk in Straduny in spring of 1987. More over a new species namely Olpidium pendulum was found in Lake Wydminy in spring of 1987. Achlya oblongata occurred in from of March to April 1990 in the southern part of Lake Elk, Rajgrodzkie, Krzywc Rajgrodzkic, Toczyłowo and River Golubica. In Lakes Ełk, Lasmiady and Selmęt Wielki a parasitic fungus Zoophthora conica was linown to occur, whereas Z. curvispora was only found in Lake Lasmiady. The development of Cylindrocarpon aquaticun was observed in Lake Rekelt, Descalsia cruciata - in Lake Henzelewo and Tricladium patulum - in Lake Ełk. Skirgiella septigena was observed in the water of Lake Etk collected from ice in the central part of the lake in the middle of March 1988. Lagenidium rabcnhorstii grew in the water of Lake Selmęt Wielki at the site in Szeligi in September 1987. Dangcardia laevis was encountered in March 1990 in Lake Ełk, while Septolipidium lineare in April of the same year in Lake Nieciecz.

Altogether, 44 species of aquatic fungi were found over the period of one year in the southem part of Lake Ełk (Table 4). Most species appeared in one month, altough such species as Aphanomyces irregularis, Achlya megasperma, Saprolegnia ferax, Fusarium aquaeductum and $A$. irregularis and $S$. ferax were found more frequently. Achlya megasperma occurred only from September to December. 
Table 4

Hydromyceflora in south part of Lake Elk in particular months

\begin{tabular}{|c|c|}
\hline Class and species & Month \\
\hline \multicolumn{2}{|l|}{ Chytridiomycetes } \\
\hline Asterophlyctis imregularis Karling & $1 \mathrm{X}$ \\
\hline Blastocladiopsis parva (Whiffen) Sparrow & I.V \\
\hline Catenaria anguillulae Sorokin & vi \\
\hline C. verrucosa Karling & $\mathrm{vi}$ \\
\hline Catenophlyetis variabilis (Karling) Karling & vil \\
\hline Dangeardia laevis Sparrow et Bart & III \\
\hline Nowakow skiel la elegans (Nowak.) Schrocter & III. IV, VI \\
\hline Oipidium granulatum Karling & $\mathrm{xII}$ \\
\hline Phlyctochyonem aereliac Ajello & III, $x$ \\
\hline Polychytrium aggregatum Ajello & IV, $\mathrm{x}$ \\
\hline Rhizophydium keralinophilum Karling & IV, V \\
\hline R. pollinis pini (Braun) Zopf & IV, VI \\
\hline \multicolumn{2}{|l|}{ Hyphoehytriomyeetes } \\
\hline Hyphochytrium estenoides Karling & $x$ \\
\hline \multicolumn{2}{|l|}{ Oomycetes } \\
\hline Acblya megasperma Humprey & IX, X, X1, XII \\
\hline A. oblongata de Barty & III, IV \\
\hline A. oligacantha de Barry & 1. III, V \\
\hline A. recurva Coms & vin \\
\hline Aphanomyces irregularis Scott & I, III, IV, V, VH, VII, IX, X, XI, XII \\
\hline A. parasiticus Coker & $\mathrm{xII}$ \\
\hline A. scaber de Barry & $\mathrm{xI}$ \\
\hline A. stellarus de Barry & $1,1 \mathrm{X}$ \\
\hline Apodachlya brachynema (Hildebr.) Pringshcim & $\mathrm{x}$ \\
\hline Cladolegnia unispora (Coker et Couch) Joh. & $\hat{\text { iI }}$ \\
\hline Dictyuchus monosporus Leitgeb & VII, IX, X \\
\hline Leptomitus lacteus (Roth) Agandh & iv \\
\hline Mitochytridium regale Hassan & v \\
\hline Olpidiopsis suprolegniac (Braun) Comu & III. $\mathrm{V}$ \\
\hline Pythiogeton nigricans Batko & IX \\
\hline Pythiem debaryanum Hesse & il \\
\hline Saprolegnia fcrax (Gruith) Turnet & III, v, vil. X, X1, XII \\
\hline S. monoica Pringsheim & LX \\
\hline S. purasitica Coker & u \\
\hline Zoophages insidians Sommerstorif & $\mathrm{DX}$ \\
\hline \multicolumn{2}{|l|}{ Zygomycetes } \\
\hline Zoophthora conica (Nowakowski) Batko & vi \\
\hline \multicolumn{2}{|l|}{ Endomycetes } \\
\hline Candida afbicans (Rabin) Berkhout & v \\
\hline Trichosporon eutaneum (de Beur, et all) Ota & II \\
\hline \multicolumn{2}{|l|}{ Hyphomycetes } \\
\hline Anguillospora iongissima (Sacc, et Sydow) Ingold & xII \\
\hline Anthroboutrys oligospora Fresenius & IV, V1 \\
\hline Bacillispora zquatica Nilsson & viII \\
\hline Fusarium aquaeductum (Radkl et Rab.) Lagerheim & 1. VIII, $X, X 11$ \\
\hline Lemonniera aquatica de Wildeman & $\mathrm{IX}, \mathrm{XI}$ \\
\hline Robillarda phragmitis Cunne & $\mathrm{xin}$ \\
\hline Tetrachactum elegans Ingold & $1 \mathrm{X}$ \\
\hline $\boldsymbol{T}$. setigerum (Grove) Ingold & i \\
\hline
\end{tabular}


cont. Table 4

\begin{tabular}{|c|c|c|c|}
\hline Month & Number of species & Scasan & Number of apecics \\
\hline 1 & 6 & Winter (X11, I, II)* & 6.0 \\
\hline II & $\begin{array}{l}4 \\
8\end{array}$ & Spring (III, IV, V) & 8.7 \\
\hline III & $\begin{array}{l}8 \\
9\end{array}$ & Summer (VI, VII, VIII) & 4.3 \\
\hline TV & $\begin{array}{l}9 \\
9\end{array}$ & Autumn (IX, X XI) & 7.7 \\
\hline $\begin{array}{l}\text { v } \\
\text { VI }\end{array}$ & $\begin{array}{l}9 \\
6\end{array}$ & & 7.7 \\
\hline VII & 4 & & \\
\hline VIII & 3 & & \\
\hline IX & 10 & & \\
\hline$x$ & 8 & & \\
\hline $\mathrm{XI}$ & 5 & & \\
\hline XII & 8 & & \\
\hline
\end{tabular}

- Samples were collected in third decade of each month

\section{DISCUSSION}

Species which are new the hydromycoflora of Poland belong to aquatic saprophytes (S p a r r o w, 1960). Olpidium pendulum has been encountered in watery soil and in water on decaying vegetal remnants (J o h n 5 o n, 1969). Cladolegnia asterophora, which is an aquatic and soil saprophyte, has been most frequently reported in winter, from soil only at temperatures below zero. In our investigations water samples were collected from the River Ełk on 25th March, when fields were covered with snow and lakes with ice. Achlya oblongata regarded as a parasite of injured fish is rather known as an aquatic zoo- and rarely phytosaprophyte ( $\mathrm{J}$ o h nso $\mathrm{n}, 1956$ ). Whereas Culvularia Iunata belongs to the group of keratinophilic fungi (Nity and a ct al., 1962; Eng lis h, 1965). Candida albicans was observed in the water of Lake EHk. However this species of yeast is also inclassified to within keratinophilic fungi (Ka p i c a, B l a n k, 1957; C z e c zuga, M u s z y ńska, 1994).

The results obtained reveoled that in Lake Rekelt a representative of Hyphomycetes - Cylindrocarpon aquaticum - was found in September, and in Lake Henzelewo another representative of the same group of Hyphomycetes fungi Descalsia cruciata - was observed at the same time. Cylindrocarpon aquaticum described by $\mathrm{N}$ i 11 s s o $\mathrm{n}(1962)$ as Bacillispora aquatica was classified by $\mathrm{M}$ a r v a$\mathrm{n} \circ \mathrm{va}$ and D e s c $1 \mathrm{~s}$ (1987) as another species of the fungus. Descaisia cruciata was for the first time isolated by $\mathrm{R} \mathrm{ol} \mathrm{d} \mathrm{a} \mathrm{n}$ and $\mathrm{H}$ o n r u b i a (1989) from foam in Canda de los Mojones stream, Riopar, Albacete, Spain in December 1987. The report on its presence in Lake Henzelewo in Mazury establishes the second site in the world and cxtends the group of water bodies where it can be found.

Particular attention should be poid to a relatively rare Hyphomycetes representative - Tricladium patulum - which was found in the coastal region of the western bank of the southern side of Lake Eik in May 1991. It was first described on ash tree leaves (Fraxinus excelsior) or decaying in running water in Czechoslovakia (M a r v a n o va, M a r van, 1963). Subsequently it was reported from Japan (T uba k i, 1966). Great Britain (A b d u $/ 1$ a h et al., 1981) and from two sites in the 
Asiatic part of the former Soviet Union (D u d k a, 1985). The analysis of the water at this site in May, when samples were collected from Lake Ełk, revealed the lowest total alkanity and nitrate nitrogen concentration, but the highest nitrate and sulphate contents.

Two other rare species of the Polish hydromycoflora belong to the group of parasitic species. Skirgiella septigena, a parasite of other species of aquatic fungi, has been hitherto encountered in the mycelium of species of the genera Achlya and Saprolegnia. While studying the occurrence of aquatic fungi in various water bodies of northeastern Poland Skirgiella septigena has only been found in the melting snow water in mixed forest ( $C$ z e c $<$ u g a, 1992). It should be noted that Lake Ełk, where Skirgiella septigena was found in March 1988, was covered with ice. Lagenidium rabenhorstii is a parasite of filiform algae of Chlorophyceae, especially of species of the genera Spirogyra, Zygnema and Oedogonium. It has been observed from early spring to mid summer. In Lake Selmęt Wielki, Lagenidium rabenhorstii was found on 17 September 1987. Our studies of the hydromycoflora of northeastern Poland revealed that Lagenidium rabenhorstii occurred only in the River Bohdanka, a right tributary of the River Narew (C z c c z u g a, 1994).

Dangeardia lacvis and Septolpidium lineare are parasites of algac. The former in most cases paralyse the cells of species of the genus Gienodinium, the latter - the cells of Synedra (S p a r r o w, 1936). Dangeardia lacvis was observed in spring and autumn in the River Narew (C z c c z u g a, W o r o n o w i c z, 1994). Special attention should be poid to Zoophthora conica a parasite of Tendipediae - which was found in the waters of Lakes Ełk, Selmęt Wielki and Lasmiady whereas Zoophthora curvispora parasite of Simuliidac - occurred in Lake Lasmiady. Zoophthora conica was found in May 1991 in the southern part of the western bank of Lake Exk and at the site in Mrozy in Lake Selmęt Wielki. Hydrochemical analysis of the water in Lake Selmet Wielki at the Mrozy site revealed the lowest ehemical oxygen demand and sulphate content, compared with other sites in this Lake. In Lake Elk Zoophthora conica also occurred in June in the castern region of the southern part. Zoophthora curvispora was encountered in Lake Lasmiady in June 1991. The chemical properties of water of Lake Lasmiady did not differ considerably from those thewalens of other lakes of this group. The development of both Zoophthora conica and Z curvispora was observed on dead insects collected in foam of the water adjacent to a sandy beach.

Monthly investigations of the same site of Lake Elk showed that the highest mean number of sepeies occurred in spring (8.7) and autumn (7.7), whereas the lowest in summer (4.3). A similar phenomenon, was observed in Lake Euknajno ( $\mathrm{C}_{2} \mathrm{e}$ c zu g a et al., 1990) and Śniardwy (C z e c z u g a, 1991).

\section{REFERENCES}

A bdullah S. C. DescalsE. We bstee J. 1981. Teleomorphus of three aquatic hyphomycetes. Trans. Be, mycol, Soe. 77: 457-483.

Atnold G. R. W, 1968. Metheds of collection and studyiaz fresh water Hyphomycetss. Mycol. Phytopathal. 2: $158-160$ 
B a tko A. 1975, Zarys hydronikologii. PWN, Warszawa.

C zeczuga B, 1987. The genesis of the lakes in north-eastem Poland. Intemat. Project on Paledimnology and late Cenozoie Climate, Kyoto, Japan, 4:31-33.

C zeczuga B. 1991. Aquatic fungi in lake Śniardwy and eighteen neighbourin lakes. Int. Revue ges. Hydrobicl, 76: 121-135.

$\mathrm{Czeczug}$ a B. 1992. Aquatic fungi in the water of melting snow. Acta Mycol. 27: 257-265.

$\mathrm{C} x \in \mathrm{Cz}$ is $\mathrm{g} \mathrm{B}$ B. 1994. Aquatic fungi of the Narew river and its tnbutanes in the strecht from Siemiandwika to Doktorce. Rocz. AM Bialystok 39 , in press.

CzeczugaB.Chomu fow sk a H., WorouowiczL. 1990. The hydronycoflora of the Biosphere Sanctuary, lake Luknajno. Acta Mycol. 26: 37-41.

Czeczuga B. M u s z y n s Ka E., 1994. Keratinephilic fungi in various types of water bodies. Acta Mycal..29: 201-215

C2 eczuga B., Or low sk a M. W or on ow ic z L., 1989, Some rare species Hyphomycetes in north-eastern Polind. Acta Mycol. 25:5:20.

C z eczuga B., Proba D., 1980. The characteristics of the envifonment of Sommerstorffia spinosa (Oomycetes: Saprolegniales), a parasite of certain rotifers. Mycologia 72: 702-707.

$\mathrm{C} z$ eczuga B., Wor on ow i ez L., 1994. Fungal parasites of algat in the waters of nort-eastern Foland with reference to the environment. Acta Mycol. 29:99-108.

De dk a I. A, 197.4. Wodini hifomiceti Ukraini, Kijew, Nauk. Dumka.

De d K a L. A., 1985, Wodnyje nesowerszennyje griby SSSR. Kijew, Nauk. Dumka.

En $g$ l i s h M. P. 1965. The saprophytic growth of non-keratinophilic fungi on keratinized substrata. and a comparison with keratinophilic fungi. Trans. Brit, mycol, Soc, $48(2): 219-235$.

Fuller M. S, J a w or s ki A, 1986. Zoosporic fungi in teaching and rescarch. Southeasiern Pabl. Corpor. Athens, $310 \mathrm{p}$

Gotterm an H. L., Cly mo R. S. 1971. Methods for physical and chemical analysis of fresh water. IBP Handbook No 8 , Oxford Blackwell Sci. Publs.

In g o I C. T., 1975. An illustrated guide to aquatic and waler bome Hyphemyetes (Fungi imperfecti) with notes on their biology. Freshwater. Biol, Assoc. Sci, Publ. 30; 1.96.

J o h n s o n T. W.. 1956. The genus A chlyax morphology and taxonorny. Ann Arbor., Univ. Michigan Press. $180 \mathrm{pp}$

J ohnsenT. W, 1959. Aquatic fungi of Iceland: Oipidiem (Braun) Rabenhorst Arch. Mikroviol. 69: 1-11.

Ka pi ca L., B I a N F., 1957, Growth of Candida albicans on keratin as scle source of nitrogen, Dematologica, 115:81-105.

Ka f l i ng J. S., 1977. Chytridiomycetarum Iconographia. An Illustrated and Brief Deseripkive Guide to the Chytridiomyectous geaere with a supplement of the Hypochytrionacetes. Vaduz.

M arva nova L. Descals E., 1987, New taxa and new combinations of "aquatic Hyphomyceter'. Trans. Bt. mycol. Soc. 89:499-507.

Ma rva n o va L. Ma f va n P. 1963. Nekolik hyphornycetú $z$ tekoucich vod Hrubeho Jesionikú. Acta Mus. Silesiae, Ser. A, 12:101-118.

Nils so a S. 1962. Sccond note Swodish fresh-water Hyphomycetes. Bot. Not.115: 73-86.

Nityan anda K. Sivasubrama niam P. A jeflo L. 1962. Mycotic keratitis caused by Curularia lunita: case report, Sabouraudia 2: 35-39.

Ro I da n A. H o n ru bi a M. 1989. Descalsia a new aquatic hyphomycete anomoph genus. Mycol. Res. 92: 494-497.

Skirgiello A., 1954. Grzyby nizsze. Warszawa.

S patrow F. K. 1936. A contribution to our knowlende of the aquatic Phytornyceles of Giteat Britain. J. Linn Soc. London (Bot) 50:417-478.

Sp artow F. K. 1960. Aquatic Phytomycetex. Ann Arbor. Univ. Michigan Press, 1187 p.

Tu ba ki K. 1966. And underscribed species of Hymenoscyphus, a perfectstage of Varicosporium. Trans. Bi, mycol. Soc, 49:345-349. 